\title{
Covid-19 in Chile. The experience of a Regional reference Center. Preliminary report.
}

Título en español: Covid-19 en Chile. Experiencia en un centro de referencia regional. Reporte preliminar.

Felipe Olivares ${ }^{1}$, Daniel Muñoz ${ }^{2,3}$, Alberto Fica ${ }^{1,4}$, Ignacio Delama ${ }^{1,4}$, Ignacia Alvarez ${ }^{5}$, Maritza Navarrete ${ }^{6,7}$, Eileen Blackburn ${ }^{8}$, Pamela Garrido ${ }^{7}$, Juan Grandjean ${ }^{9}$.

${ }^{1}$ SubDepartamento de Medicina, Hospital Base de Valdivia, Valdivia, Chile

${ }^{2}$ Servicio de Farmacia, Hospital Base de Valdivia, Valdivia, Chile.

${ }^{3}$ Instituto de Farmacia, Facultad de Ciencias, Campus Isla Teja, Universidad Austral de Chile, Valdivia, Chile

${ }^{4}$ Instituto de Medicina, Facultad de Medicina, Campus Isla Teja, Universidad Austral de Chile, Valdivia, Chile

${ }^{5}$ Carrera de Química y Farmacia, Facultad de Ciencias, Campus Isla Teja, Universidad Austral de Chile, Valdivia, Chile

${ }^{6}$ Laboratorio de Virología, Instituto de Microbiología Clínica, Faculta de Medicina, Universidad Austral de Chile.

${ }^{7}$ Laboratorio de Biología Molecular, Hospital Base de Valdivia, Valdivia, Chile.

${ }^{8}$ Servicio Laboratorio Clínico, Hospital Base de Valdivia, Valdivia, Chile

${ }^{9}$ Unidad de Pacientes Críticos, Hospital Base de Valdivia, Chile. 
medRxiv preprint doi: https://doi.org/10.1101/2020.06.14.20130898; this version posted June 16, 2020. The copyright holder for this preprint (which was not certified by peer review) is the author/funder, who has granted medRxiv a license to display the preprint in perpetuity.

\section{Correspondence to:}

\section{Dr.Alberto Fica Cubillos}

Médico Infectólogo, SubDepartamento de Medicina, Hospital Base de Valdivia

Bueras 1003, Valdivia, Región De Los Ríos, Chile

Instituto de Medicina, Facultad de Medicina, Campus Isla Teja, Universidad Austral de Chile, Valdivia, Chile

Email: albertoficacubillos@gmail.com / Teléfono: +56992408638

Conflict of interest None / Funding: None

Tables: 4; Figures: 3 
medRxiv preprint doi: https://doi.org/10.1101/2020.06.14.20130898; this version posted June 16, 2020. The copyright holder for this preprint (which was not certified by peer review) is the author/funder, who has granted medRxiv a license to display the preprint in perpetuity.

\begin{abstract}
During the first pandemic wave Covid-19 reached Latin America cities. Aim: To report clinical features and outcomes associated to Covid-19 in a group of patients admitted during the first wave in a regional reference Center in southern Chile designated to severe and critical cases. Methods: Cases were identified by a compatible clinical picture associated to positive RT-PCR or serological testing. A standard protocol was applied.

Results: 21 adult patients (20 diagnosed by PCR, one by serology) were admitted between epidemiological weeks 13 to 20, involving $8.8 \%$ of total regional cases. Hospitalization occurred at a median of 11 days after symptoms onset. Patients $\geq 60$ years old predominated (57.1\%). Hypertension (61.9\%), obesity (57.1\%) and diabetes mellitus $2(38.1 \%)$ were prevalent but $19 \%$ had no comorbid conditions nor were elderly. Two cases involved second-trimester pregnant women. Positive $\operatorname{IgM}$ or $\operatorname{IgM} / \operatorname{IgG}$ results obtained by rapid serological testing were limited (19\% at 1 st week; $42.9 \%$ at 2 nd week). Nine patients (42.9\%, critical group) were transferred to ICU and connected to mechanical ventilation due to respiratory failure. By univariate analysis admission to ICU was significantly associated to tachypnea and higher plasmatic LDH values. One pregnant woman required urgent cesarean section given birth to a premature neonate without vertical transmission. Two patients died (in-hospital mortality 9.5\%) and length of stay was $\geq 14$ days in $57.9 \%$ of patients. Conclusion: In our regional Center, Covid 19 was associated to known risk factors, had a prolonged stay and in-hospital mortality. Tachypnea $\geq 30 / \mathrm{min}$ is predictive of transfer to ICU.
\end{abstract}

Keywords: Covid-19; pneumonia; critical care; serologic tests; Real-time PCR 
medRxiv preprint doi: https://doi.org/10.1101/2020.06.14.20130898; this version posted June 16, 2020. The copyright holder for this preprint (which was not certified by peer review) is the author/funder, who has granted medRxiv a license to display the preprint in perpetuity.

\section{Introduction}

Covid-19 is an emerging disease caused by the SARS-CoV-2 virus and first reported in late 2019 in China (1). Due to its rapid expansion, on March 2020 it was declared a global pandemic by the WHO (2) and up to date has affected more than 6 million habitants worldwide of whom 379,941 have died (3). The first case reported in Chile was registered on March $3^{\text {rd }}$ and at the beginning of June 105,000 cases has been reported with more than a thousand people deceased (4). The temporal evolution of this epidemic is unknown, but it has been estimated that it could generate recurrent outbreaks and remain in circulation for a long time (5). Currently there is little information on the clinical presentation of Covid-19 and outcomes in Latin America, especially in hospitalized patients (6-9). This could contrast with that reported in countries of the northern hemisphere, which have dissimilar features on demographic, economic, cultural, healthcare systems and/or mitigation strategies issues (10-19). We present this preliminary report on a cohort of Covid-19 patients during the first wave in a southern region in Chile detailing clinical features and outcomes in a reference center.

\section{Patients and Methods}

Study design, inclusion criteria and laboratory tests. Retrospective descriptive study of patients admitted during the first wave at the Hospital Regional of Valdivia, in southern Chile. Patients were included, if had suspicious symptoms plus either a positive SARSCoV-2 RT-PCR or a rapid serological test coupled with compatible chest-CT imaging. For RT-PCR tests, nasopharyngeal swab samples were obtained and placed in viral transport medium. Total nucleic acids were extracted from $200 \mu \mathrm{L}$ of transport medium with Chemagic Prepito Instrument using Prepito Viral DNA / RNA Kit (Both PerkinElmer TM) according to manufacturer's recommendations and eluted in $100 \mu \mathrm{L}$ of an elution buffer. SARS-CoV-2 RNA was detected using the Primerdesign COVID-19 Genesig Real-Time PCR assay and the amplification reaction was performed in a Bio-Rad® CFX96 thermocycler according to manufacturer's instructions. Specimens were considered positive if the $\mathrm{Ct}$ value was $<37$ and the internal controls were detected. In parallel, the quality of 
medRxiv preprint doi: https://doi.org/10.1101/2020.06.14.20130898; this version posted June 16, 2020. The copyright holder for this preprint (which was not certified by peer review) is the author/funder, who has granted medRxiv a license to display the preprint in perpetuity. It is made available under a CC-BY-NC-ND 4.0 International license .

the samples was checked with a human RNAse P Real-Time PCR assay with the CDC primers from IDT. Serology was performed using the "VivaDiag COVID $\square 19$ IgM / IgG Rapid Test lateral flow immunoassay (LFIA)" kit based on the addition of $10 \mu \mathrm{L}$ of serum and then 2 to 3 drops of $(70-100 \mu \mathrm{L})$ buffer dilution. Results were read after 15 minutes.

Regional management protocol. Los Ríos Region has an estimated population of 406,000 inhabitants (20). Most of the population (> 80\%) is cared for in an integrated network of primary care centers and low-complexity hospitals, with only one high-complexity reference center (Hospital Regional) designated to receive severe and critically ill Covid-19 patients. Severity illness stratification was performed based on a regional clinical care guideline using the following classification: a) Mild: no need of oxygen therapy or hospitalization, b) Moderate: low oxygen requirement (FiO2 <32\%); $\mathrm{PaO}_{2} / \mathrm{FiO}_{2}$ ratio $\geq$ 200 , respiratory rate $<30 / \mathrm{min}$, and no shock or organ dysfunction, c) Severe: $\mathrm{FiO}_{2} 32-$ $40 \% ; \mathrm{PaO}_{2} / \mathrm{FiO}_{2}$ ratio $\geq 200$, respiratory rate $\geq 30 / \mathrm{min}$, without shock or organ dysfunction, and d) Critical: $\mathrm{FiO}_{2}>40 \% ; \mathrm{PaO}_{2} / \mathrm{FiO}_{2}$ ratio <200, septic shock, organ dysfunction, chest x-ray with bilateral infiltrates and / or requirement for invasive mechanical ventilation (IMV). Patients in severe or critical conditions were transferred to the Regional Hospital. The guideline considered the use of hydroxychloroquine (HQ; day 1: 400mg every $12 \mathrm{hrs}$, day 2-5: 200mg every $12 \mathrm{hrs}$ ) in all admitted patients as well as those $>60$ years and / or with chronic diseases. All admitted patients received a beta-lactam antibiotic and pharmacological prophylaxis for thromboembolic disease. Besides, critical patients with a D-dimer (DD) value > 6 times the normal value were prescribed with an intermediate heparin dose (unfractionated formulation 5,000 UI every 8 hours or enoxaparin $1 \mathrm{mg} / \mathrm{kg} /$ day). The use of glucocorticoids and convalescent plasma were indicated according to the criteria of physicians in charge.

Clinical characterization and outcomes. Demo-epidemiological variables, pregnancy status and comorbidities as well as clinical features were retrieved from medical records. The CALL score was calculated as described (21) as well SOFA and APACHE II in those 
medRxiv preprint doi: https://doi.org/10.1101/2020.06.14.20130898; this version posted June 16, 2020. The copyright holder for this preprint (which was not certified by peer review) is the author/funder, who has granted medRxiv a license to display the preprint in perpetuity.

admitted to the ICU. Pharmacological therapies, complications, clinical outcomes, length of stay and in-hospital mortality were extracted and calculated from medical records.

Statistical analysis and ethical issues. Data corresponding to quantitative variables is presented as medians with interquartile range (IQR) and categorical variables as percentages. Analysis of potential factors associated with ICU admission was performed with non-parametric tests such as the Fisher or the Mann-Whitney test. Some graphs were fitted with the least squares method to facilitate trends reading. This work was approved by the Institutional Review Board.

\section{Results}

Cases identified and epidemiological features. Twenty-one patients were admitted to our hospital between epidemiological weeks 13 and 20, a group that compose this preliminary report. During this timeframe, hospital admissions at our center (all in severe or critical condition) represented $8.8 \%$ of the total reported cases in the region (21 out of 237). Figure 1 shows the impact of the first wave on admissions at our reference center. Admissions (to all units or ICU) decreased secondary to mitigation measures.

Clinical features. Median age was 61 years (range 26-85 years, IQR 51-68 years) and more than half were $\geq 60$ years old (Table 1). Female patients predominated and contact with a known Covid-19 case was frequent. A healthcare worker integrates this report whose contagion occurred in a primary care center. Hypertension, obesity, and type 2 diabetes mellitus were prevalent (Table 1). Two patients were pregnant and 19\% had no comorbid history. The use of active drugs on the renin-angiotensin-aldosterone system approached $40 \%$ of the series (Table 1). Predominant symptoms in order of frequency were cough, dyspnea, and fever followed by myalgia, odynophagia, and headache. Anosmia and dysgeusia were reported in about a quarter of patients. Diarrhea and rhinorrhea were infrequent but observed in about a fifth of cases (Figure 2). Arterial hypotension on admission was infrequent $(9.5 \%)$. The median symptomatic period before admission was 
medRxiv preprint doi: https://doi.org/10.1101/2020.06.14.20130898; this version posted June 16, 2020. The copyright holder for this preprint (which was not certified by peer review) is the author/funder, who has granted medRxiv a license to display the preprint in perpetuity.

11 days (IQR 5-13 days, Figure 1). About half of our patients were admitted with tachypnea and an abnormal $\mathrm{PaO}_{2} / \mathrm{FiO}_{2}$, but low $\mathrm{O}_{2}$ saturation on pulse oximetry or hypoxemia in arterial gases was less frequent (Table 2). We did not observe patients with leukocytosis or neutrophilia. In contrast, the fraction of patients with lymphopenia (42.9\%) and to a lesser degree, thrombocytopenia $(23.8 \%)$ was relevant. The series also highlights the high frequency of patients with elevated LDH and ferritin plasmatic values $(>70 \%$, Table 2). Coagulation parameters (International Normalized Ratio and activated partial thromboplastin time) did not show major alterations, but DD values were elevated in about half of patients.

Management, complications and outcome. Approximately 40\% (9/21) of patients were transferred to ICU (Table 3), all requiring IMV with median SOFA and APACHE II scores of 4 points (range 2-9) and 12 points (range 3-20), respectively. Half of the patients had a CALL score in the highest severity range (10-13 points, Table 3$)$. The use of vasoactive drugs was required in 8 of the 9 patients with IMV. All the patients received by protocol, HQ and about half also azithromycin. Furthermore, 5 of the 21 patients received steroid therapy $(23.8 \%$, Table 3$)$. Corticosteroids were indicated in patients with refractory ARDS (methyl prednisolone), refractory shock (hydrocortisone), obstructive bronchitis (hydrocortisone), thrombocytopenic purpura (dexamentasone) and to achieve fetal maturation (betamethasone) in a pregnant woman. In the latter case, she had a 28 weeks pregnancy and underwent an urgent cesarean section, receiving the only convalescent plasma therapy in the series shortly before delivery. She had a premature newborn weighing 1540 grams, with hypotonia, intraventricular hemorrhage, seizures, neonatal jaundice and later bacteremia, requiring IVM connection and application of pulmonary surfactant. Perinatal transmission of SARS-CoV-2 was ruled out. Until the time of publication, he was still hospitalized in the neonatal ICU.

Among observed complications, Acute Respiratory Distress Syndrome (ARDS) was recorded in 9 patients (42.9\%), nosocomial infections in 33.3\%, and Acute Kidney Injury in $28.6 \%$ (with dialysis requirement in one of them). An isolated prolonged QTc interval event was registered but without arrhythmia (Table 3). Health care-associated infections 
medRxiv preprint doi: https://doi.org/10.1101/2020.06.14.20130898; this version posted June 16, 2020. The copyright holder for this preprint

included 3 events of bloodstream infections, 2 of ventilator-associated pneumonia, 1 of urinary tract infection, and one of fever without an identified source. Median hospital stay was 18 days with more than half remaining hospitalized $\geq 2$ weeks. Two of our patients died (in-hospital mortality 9.5\%) at 35 and 38 days after admission due to central venous catheter-associated bloodstream infection and refractory ARDS, respectively.

Serological and molecular studies. All patients underwent a rapid serologic test to detect $\operatorname{IgM} / \mathrm{IgG}$ antibodies. After the first round (taken at different weeks of symptoms onset), most showed $\operatorname{IgM}+/ \operatorname{IgG}+(81 \%)$ or isolated $\operatorname{IgM}+(9.5 \%)$ antibodies (Table 4$)$. Negative and invalid results were also observed. A second round of examinations carried out in the 4 patients with negative, invalid or isolated positive IgM results, demonstrated seroconversion to $\mathrm{IgM}+/ \mathrm{IgG}+$ in all of them. Rapid test sensitivity during the first round increased according to the elapsed time but was low during the first 3 weeks (19\% to $61.9 \%$, Table 4, Figure 3).

Comparison of critical versus non-critical group. An exploratory analysis was performed to identify possible factors associated with a transfer to ICU. A critical evolution was not associated with increased age, gender, comorbidities, pregnancy, or a higher CALL score (data not shown). However, 2 factors appeared linked to ICU admission: tachypnea and elevated plasma LDH values. Seven out of 9 patients with a critical condition had tachypnea vs. 3 out of 12 without a critical condition (OR 10.5; IC95 1.36-81; p <0.05). Plasmatic LDH values in the critical group had a median of 467 U/L (IQR 427-493) versus 267.5 U/L (IQR 238-305) in the non-critical group ( $<<0.05$ ). Due to the small size of the groups, a multivariate analysis was not attempted.

\section{Discussion}

After attacking China, Europe, and the United States, the epicenter of the Covid-19 pandemics is centered currently in Latin America. However, there is little information on the clinical features, management, and outcome for this infection in our region. This work 
medRxiv preprint doi: https://doi.org/10.1101/2020.06.14.20130898; this version posted June 16, 2020. The copyright holder for this preprint

contributes to the knowledge of this infection in the Latin American context and communicates its preliminary results. Patients were managed using a protocol built according to the best evidence available at the time of its preparation (22-25) and although the pharmacological therapies initially contemplated are currently questioned or disregarded (26-30), the existence of a guideline made it possible to work in a uniform manner in a whole region of southern Chile.

As in other experiences, we were able to confirm that hospital admissions occur several days after the onset of symptoms, that less than $10 \%$ of all cases require hospitalization and that hospital stay is prolonged (10,17). Patient characteristics reflect the weight of comorbidities and advanced age, involvement of healthcare personnel or pregnant women, and known systemic and respiratory symptoms in addition to changes in taste or smell and occasionally gastrointestinal manifestations. In our series, ICU admission for critical conditions was very high (about $50 \%$ of admissions) because our center concentrates severe and critical patients of the region. All patients received HQ per protocol, a drug whose efficacy and safety has recently been questioned $(26,27,31)$. In our series, only one case of QTc prolongation was observed and none presented arrhythmias.

Steroid therapy was applied on a case-by-case basis for different reasons and not by protocol, since there is no consensus regarding its use. Although the available evidence has not been consistent $(32,33)$, some experiences have suggested that administration could increase survival (34-36). Its use in turn, must be balanced with its known association with infectious complications, myopathy, delirium, hyperglycemia, gastrointestinal bleeding or hydro-electrolyte disorders (37). ARDS secondary to other viral etiologies have been associated with a delayed viral clearence $(38)$ or even increased mortality $(33,39)$. Currently, some prospective projects are underway that could solve these questions.

There were 2 patients carrying a second trimester pregnancy who presented with pneumonia and respiratory failure due to SARS-CoV-2, one of them with severe illness that responded to conventional $\mathrm{O}_{2}$ therapy without fetal or maternal complications. The second 
medRxiv preprint doi: https://doi.org/10.1101/2020.06.14.20130898; this version posted June 16, 2020. The copyright holder for this preprint (which was not certified by peer review) is the author/funder, who has granted medRxiv a license to display the preprint in perpetuity.

It is made available under a CC-BY-NC-ND 4.0 International license .

evolved in a critical condition, requiring IMV, and prompt fetal lung maturation with corticosteroids. Fortunately her evolution was favorable after an urgent cesarean section and convalescent plasma therapy. The impact of this infection in pregnancy is beginning to be delineated with no intrauterine transmission events or maternal mortality so far reported and with most of the deliveries managed by Cesarean sections (40). Fetal consequences may include intrauterine growth retardation, cyanosis, gastrointestinal bleeding, and neonatal mortality (40).

Convalescent plasma is an experimental potentially beneficial therapy $(41,42)$ that has shown an adequate safety profile (43). Recently, a randomized clinical trial reported a trend towards a higher proportion of patients with clinical improvement (28 days) and lower mortality in the plasma-receiving group (44).

Laboratory tests showed an inflammatory state (elevated C-reactive protein, ferritin and plasmatic LDH levels) and procoagulant status (increased DD). The relevance of tachypnea and elevated plasma LDH in the identification of critically ill patients was confirmed. These results are consistent with other studies where increased LDH values had a high sensitivity (100\%) and specificity (86.7\%) to predict severe disease (45). In our report, the low number of cases prevented confirming other variables associated with severity or adverse prognosis such as advanced age, high fever, chronic diseases (especially chronic cardiovascular or pulmonary disease, diabetes and high blood pressure), coagulopathy, increased D-dimer, troponin or ferritin levels, neutrophilia, lymphopenia, and/or leukocytosis $(34,46-49)$.

Serology by a rapid antibody-based test was performed in all patients with $19 \%$ and $42.9 \%$ sensitivity in the first and second week, respectively, consistent with other reports $(50,51)$ that reinforce its limited utility for early diagnosis. However, it can be helpful when a high suspicion exists despite serial negative RT-PCT and compatible symptoms and chest-CT images as happened in one of our patients. 
medRxiv preprint doi: https://doi.org/10.1101/2020.06.14.20130898; this version posted June 16, 2020. The copyright holder for this preprint

(which was not certified by peer review) is the author/funder, who has granted medRxiv a license to display the preprint in perpetuity.

It is made available under a CC-BY-NC-ND 4.0 International license.

Complications observed underline the high frequency of ARDS and healthcare associated infections which in turn explained death of our patients (52). Autopsy studies have revealed the presence of diffuse alveolar damage, in exudative and proliferative phases, including alterations such as capillary congestion, pneumocyte necrosis, hyaline membrane, interstitial edema, atypical and hyperplastic pneumocytes, and microthrombi in arterioles $(53,54)$. The latter support using anticoagulants in patients with high DD (55) which in observational studies has shown to reduce mortality $(56,57)$. Thus all our patients received heparin prophylaxis and in one third we use high-intermediate doses due to high DD values.

\section{Conclusions}

In our regional Center, Covid-19 was associated to known risk factors, had a prolonged stay and in-hospital mortality. Near $8 \%$ of regional cases evolved with a severe or critical illness and required to be transferred to a designated reference hospital. Tachypnea $\geq 30 / \mathrm{min}$ and high plasmatic LDH levels were predictive of transfer to ICU, mainly by ARDS. Rapid antibody-based tests were not useful for early diagnosis. Besides ARDS, hospital-acquired infections and acute kidney injury were frequent complications. As specific therapeutic alternatives have no proven effectiveness, Covid-19 management rest mainly on supportive care. 


\section{References}

1. Wu Z, McGoogan JM. Characteristics of and Important Lessons From the Coronavirus Disease 2019 (COVID-19) Outbreak in China: Summary of a Report of $72 \square 314$ Cases From the Chinese Center for Disease Control and Prevention. JAMA.

2020;323(13):1239-1242.

2. Cucinotta D, Vanelli M. WHO declares Covid-19 a pandemic. Acta Biomed 2020; Vol. 91, N. 1: 157-160.

3. World Health Organization. Coronavirus disease (COVID-2019) Situation Report 132. Disponible en: https://www.who.int/docs/default-source/coronaviruse/situationreports/20200531-covid-19-sitrep-132.pdf?sfvrsn=d9c2eaef_2. [consultado el 1 de junio del 2020].

4. Ministerio de Salud. Informe Epidemiológico n²2, Enfermedad por SARS-CoV-2 (Covid-19) en Chile (2020 June 1). Disponible en: https://www.minsal.cl/wpcontent/uploads/2020/06/Informe_EPI_010620.pdf. [Consultado el 1 de junio del 2020]

5. Kissler SM, Tedijanto C, Goldstein E, Grad YH, Lipsitch M. Projecting the transmission dynamics of SARS-CoV-2 through the postpandemic period. Science. 2020; 368(6493):860 $\square 868$. doi:10.1126/science.abb5793.

6. Valente-Acosta, Hoyo-Ulloa I, Espinosa-Aguilar L, Mendoza-Aguilar R, GarciaGuerrero J, Ontañon-Zurita D, et al. COVID-19 severe pneumonia in Mexico City First experience in a Mexican hospital. medRxiv 20080796 [Preprint].2020. Disponible en: https://www.medrxiv.org/content/10.1101/2020.04.26.20080796v1 [Consultado el 1 de junio del 2020]. 
7. Souza W, Buss L, Da D, Carrera J, Li S, Zarebski A, et al. Epidemiological and clinical characteristics of the early phase of the COVID-19 epidemic in Brazil. medRxiv 20077396 [Preprint].2020. Disponible en:

https://www.medrxiv.org/content/10.1101/2020.04.25.20077396v1[Consultado el 1 de junio del 2020].

8. Escalera-Antezana JP, Lizon-Ferrufino NF, Maldonado-Alanoca A, Alarcón-De-laVega G, Alvarado-Arnez L, Balderrama-Saavedra M, et al. Clinical features of the first cases and a cluster of Coronavirus Disease 2019 (COVID-19) in Bolivia imported from Italy and Spain. Travel Med Infect Dis. 2020;101653.

9. Ortiz-Prado E, Simbaña-Rivera K, Maria Diaz A, Barreto A, Moyano C, Arcos V. Epidemiological, socio-demographic and clinical features of the early phase of the COVID-19 epidemic in Ecuador. medRxiv 20095943 [Preprint].2020. Disponible en: https://www.medrxiv.org/content/10.1101/2020.05.08.20095943v2 [Consultado el 1 de junio del 2020].

10. Guan W, Ni Z, Hu Y, Liang W, Ou C, He J, et al. Clinical Characteristics of Coronavirus Disease 2019 in China. N Engl J Med 2020; 382: 1708-20.

11. Richardson S, Hirsch JS, Narasimhan M, Crawford J, McGinn T, Davidsonet KW, et al. Presenting characteristics, comorbidities, and outcomes among 5700 patients hospitalized with COVID-19 in the New York City Area. JAMA. 2020; 323(20): 20529. 
medRxiv preprint doi: https://doi.org/10.1101/2020.06.14.20130898; this version posted June 16, 2020. The copyright holder for this preprint (which was not certified by peer review) is the author/funder, who has granted medRxiv a license to display the preprint in perpetuity. It is made available under a CC-BY-NC-ND 4.0 International license .

12. Argenziano MG, Bruce SL, Slater CL, Tiao JR, Baldwin MR, Barr RG, et al. Characterization and clinical course of 1000 patients with coronavirus disease 2019 in New York: retrospective case series. BMJ. 2020;369:m1996.

13. Paranjpe I, Russak A, De Freitas JK, Lala A, Miotto R, Vaid A, et al. Clinical Characteristics of Hospitalized Covid-19 Patients in New York City. medRxiv 20062117 [Preprint].2020. Disponible en:

https://www.medrxiv.org/content/10.1101/2020.04.19.20062117v2 [consultado el 1 de junio del 2020].

14. Goyal P, Choi J, Pinheiro L, Schenk E, Chen R, Jabri A, et al. Clinical Characteristics of Covid-19 in New York City. N Engl J Med. 2020; NEJMc2010419.

15. Benetti E, Giliberti A, Emiliozzi A, Velentino F, Bergantini L, Fallerini C, et al. Clinical and molecular characterization of COVID-19 hospitalized patients. medRxiv 20108845 [Preprint].2020 Disponible en:

https://www.medrxiv.org/content/10.1101/2020.05.22.20108845v1 [Consultado el 1 de junio del 2020].

16. Docherty AB, Harrison EM, Green CA, Hardwick HE, Pius R, Norman L, et al.Features of 20133 hospitalised UK patients with covid-19 using the ISARIC WHO clinical characterisation protocol. BMJ 2020; 369:m1985.

17. Rojo JMC, Santos JMA MDa, Núñez-Cortés JM, Lumbreras C, Rincón JMR, RoyVallejo E, et al. Clinical characteristics of patients hospitalized with COVID-19 in Spain: results from the SEMICOVID-19 Network. medRxiv 20111971 [Preprint].2020 Disponible en: https://www.medrxiv.org/content/10.1101/2020.05.24.20111971v1 [Consultado el 1 de junio del 2020]. 
medRxiv preprint doi: https://doi.org/10.1101/2020.06.14.20130898; this version posted June 16, 2020. The copyright holder for this preprint (which was not certified by peer review) is the author/funder, who has granted medRxiv a license to display the preprint in perpetuity.

18. Borobia AM, Carcas AJ, Arnalich F, Alvarez-Sala R, Montserrat J, Quintana M, et al. A cohort of patients with COVID-19 in a major teaching hospital in Europe. medRxiv 20080853 [Preprint].2020 Disponible en:

https://www.medrxiv.org/content/10.1101/2020.04.29.20080853v2 [Consultado el 1 de junio del 2020].

19. Heili-Frades S, Minguez P, Mahillo-Fernandez I, Prieto-Rumeau T, Gonzalez AH, de la Fuente L, et al. COVID-19 Outcomes in 4712 consecutively confirmed SARS-CoV2 cases in the city of Madrid. medRxiv 20109850 [Preprint].2020. Disponible en: https://www.medrxiv.org/content/10.1101/2020.05.22.20109850v2 [Consultado el 1 de junio del 2020].

20. Instituto Nacional de Estadísticas de Chile. SÍNTESIS DE RESULTADOS CENSO 2017. Disponible en: https://www.censo2017.cl/descargas/home/sintesis-de-resultadoscenso2017.pdf [Consultado el 24 de mayo 2020].

21. Ji D, Zhang D, Xu J, Chen Z, Yang T, Zhao P, et al. Prediction for Progression Risk in Patients with COVID-19 Pneumonia: the CALL Score. Clin Infect Dis. 2020; ciaa414. doi:10.1093/cid/ciaa414.

22. Gautret P, Lagier JC, Parola P, Hoang VT, Meddeb L, Mailhe M, et al. Hydroxychloroquine and azithromycin as a treatment of COVID-19: results of an openlabel non-randomized clinical trial. Int J Antimicrob Agents 2020; 105949.

23. Chen Z, Hu J, Zhang Z, Jiang S, Han S, Yan D, Zhuang R, et al. Efficacy of hydroxychloroquine in patients with COVID-19: results of a randomized clinical trial. medRxiv 20040758 [Preprint].2020 Disponible en: 
medRxiv preprint doi: https://doi.org/10.1101/2020.06.14.20130898; this version posted June 16, 2020. The copyright holder for this preprint (which was not certified by peer review) is the author/funder, who has granted medRxiv a license to display the preprint in perpetuity. It is made available under a CC-BY-NC-ND 4.0 International license.

https://www.medrxiv.org/content/10.1101/2020.03.22.20040758v3. [Consultado el 1 de junio del 2020].

24. Yu B, Li C, Chen P, Zhou N, Wang L, Li J, et al. Low dose of hydroxychloroquine reduces fatality of critically ill patients with COVID-19. Sci China Life Sci 2020 doi: 10.1007/s11427-020-1732-2.

25. Yao TT, Qian JD, ZhuWY,Wang Y,Wang GQ. A systematic review of lopinavir therapy for SARS coronavirus and MERS coronavirus-A possible reference for coronavirus disease-19 treatment option. J Med Virol. 2020; 92:556-563.

26. Tang W, Cao Z, Han M, Wang Z, Chen J, Sun W, et al. Hydroxychloroquine in patients with COVID-19: an open label, randomized, controlled trial. BMJ 2020; 369: m1849.

27. Rosenberg ES, Dufort EM, Udo T, Wilberschied L, Kumar J, Tesoriero J, et al. Association of treatment with hydroxychloroquine or azithromycin with in-hospital mortality in patients with COVID-19 in New York State. JAMA 2020 doi: 10.1001/jama.2020.8630.

28. Geleris J, Sun Y, Platt J, Zucker J, Baldwin M, Hripcsak G, et al. Observational study of hydroxychloroquine in hospitalized patients with Covid-19. N Engl J Med 2020; NEJMoa2012410.

29. Mahévas M, Tran V-T, Roumier M, Chabrol A, Paule R, Guillaud C, et al. Clinical efficacy of hydroxychloroquine in patients with COVID-19 pneumonia who require oxygen: observational comparative study using routine care data. BMJ. 2020;369:m1844. 
medRxiv preprint doi: https://doi.org/10.1101/2020.06.14.20130898; this version posted June 16, 2020. The copyright holder for this preprint (which was not certified by peer review) is the author/funder, who has granted medRxiv a license to display the preprint in perpetuity. It is made available under a CC-BY-NC-ND 4.0 International license .

30. Cao B,Wang Y,Wen D, et al. A trial of lopinavir-ritonavir in adults hospitalized with severe COVID-19. N Engl J Med 2020; 382:1787-99.

31. Magagnoli J, Narendran S, Pereira F, Cummings T, Hardin J, Sutton S, et al. Outcomes of hydroxychloroquine usage in United States veterans hospitalized with Covid-19. medRxiv 20065920[Preprint].2020 Disponible en: https://www.medrxiv.org/content/10.1101/2020.04.16.20065920v2 [Consultado el 1 de junio del 2020].

32. Veronese N, Demurtas J, Yang L, Tonelli R, Barbagallo M, Lopalco P, et al. Use of corticosteroids in coronavirus disease 2019 pneumonia: A systematic review of the literature. Front Med (Lausanne) 2020;7. Doi: 10.3389/fmed.2020.00170.

33. Ye Z, Wang Y, Colunga-Lozano L, Prasad M, Tangamornsuksan W, Rochwerg B, et al. Efficacy and safety of corticosteroids in COVID-19 based on evidence for COVID-19, other coronavirus infections, influenza, community-acquired pneumonia and acute respiratory distress syndrome: a systematic review and meta-analysis. CMAJ. 2020 doi: 10.1503/cmaj.200645.

34. Wu C, Chen X, Cai Y, Xia J, Zhou X, Xu S, et al. Risk factors associated with acute respiratory distress syndrome and death in patients withcoronavirus disease 2019 pneumonia in Wuhan, China. JAMA Intern Med 2020 doi: 10.1001/jamainternmed.2020.0994.

35. Wang Y, Jiang W, He Q, Wang C, Wang B, Zhou P, et al. Early, low-dose and shortterm application of corticosteroid treatment in patients with severe COVID-19 pneumonia: single-center experience from Wuhan, China. medRxiv 20032342 [Preprint].2020 Disponible en: 2020: 
medRxiv preprint doi: https://doi.org/10.1101/2020.06.14.20130898; this version posted June 16, 2020. The copyright holder for this preprint (which was not certified by peer review) is the author/funder, who has granted medRxiv a license to display the preprint in perpetuity. It is made available under a CC-BY-NC-ND 4.0 International license.

https://www.medrxiv.org/content/10.1101/2020.03.06.20032342v1 [Consultado el 3 de junio del 2020].

36. Fadel R, Morrison A, Vahia A, Smith Z, Chaudhry Z, Bhargava P, et al. Early short course corticosteroids in hospitalized patients with COVID-19. Clin Infect Dis 2020; doi: 10.1093/cid/ciaa601.

37. Williams D. Clinical Pharmacology of Corticosteroids. Respiratory Care. 2018; 63(6): $655-670$.

38. Lee N, Allen Chan K, Hui D, Ng E, Wu A, Chiu R, et al. Effects of early corticosteroid treatment on plasma SARS-associated coronavirus RNA concentrations in adult patients. J Clin Virol 2004;31(4):304-309.

39. Lansbury L, Rodrigo C, Leonardi-Bee J, Nguyen-Van-Tam J, Lim WS. Corticosteroids as adjunctive therapy in the treatment of influenza. Cochrane Database Syst Rev. 2019;2:CD010406.

40. Schwartz DA. An analysis of 38 pregnant women with COVID-19, their newborn infants, and maternal-fetal transmission of SARS-CoV-2: Maternal coronavirus infections and pregnancy outcomes. Arch Pathol Lab Med 2020; doi: 10.5858/arpa.2020-0901-SA.

41. Shen C, Wang Z, Zhao F, Yang Y, Li J, Yuan J et al. Treatment of 5 critically ill patients with COVID-19 with convalescent plasma. JAMA. 2020;323(16):1582. 
medRxiv preprint doi: https://doi.org/10.1101/2020.06.14.20130898; this version posted June 16, 2020. The copyright holder for this preprint (which was not certified by peer review) is the author/funder, who has granted medRxiv a license to display the preprint in perpetuity. It is made available under a CC-BY-NC-ND 4.0 International license .

42. QL Zeng QL, Yu ZJ, Gou JJ, Li GM, MA SH, Zhang GF, et al. Effect of Convalescent Plasma Therapy on Viral Shedding and Survival in COVID-19 Patients [published online ahead of print, 2020 Apr 29]. J Infect Dis 2020. doi: 10.1093/infdis/jiaa228.

43. Joyner M, Wright R, Fairweather D, Senefeld J, Bruno K, Klassen S et al. Early Safety Indicators of COVID-19 Convalescent Plasma in 5,000 Patients. medRxiv 20099879 [Preprint].2020. Disponible en: https://www.medrxiv.org/content/10.1101/2020.05.12.20099879v1 [Consultado el 3 de junio del 2020].

44. Li L, Zhang W, Hu Y, Tong X, Zheng S, Yang J et al. Effect of convalescent plasma therapy on time to clinical improvement in patients with severe and life-threatening COVID-19. JAMA. 2020. doi: 10.1001/jama.2020.10044.

45. Han Y, Zhang H, Mu S, Wei W, Jin C, Xue Y, et al. Lactate dehydrogenase, a Risk factor of severe COVID-19 patients. 2020; medRxiv 20040162 [Preprint].2020. Disponible en: https://www.medrxiv.org/content/10.1101/2020.03.24.20040162v1. doi: $10.1101 / 2020.03 .24 .20040162$.

46. Zhou F, Yu T, Du R, Fan G, Liu Y, Liu Z, et al. Clinical course and risk factors for mortality of adult inpatients with COVID-19 in Wuhan, China: a retrospective cohort study. The Lancet. 2020;395(10229):1054-1062.

47. Shi Y, Yu X, Zhao H, Wang H, Zhao R, Sheng J. Host susceptibility to severe COVID19 and establishment of a host risk score: findings of 487 cases outside Wuhan. Critical Care. 2020;24(1). doi: 10.1186/s13054-020-2833-7. 
medRxiv preprint doi: https://doi.org/10.1101/2020.06.14.20130898; this version posted June 16, 2020. The copyright holder for this preprint (which was not certified by peer review) is the author/funder, who has granted medRxiv a license to display the preprint in perpetuity.

It is made available under a CC-BY-NC-ND 4.0 International license .

48. Hu L, Chen S, Fu Y, Gao Z, Long H, Ren H, et al. Risk Factors Associated with Clinical Outcomes in 323 COVID-19 Patients in Wuhan, China. Clin Infect Dis 2020; doi: 10.1093/cid/ciaa539.

49. Caramelo F, Ferreira N, Oliveiros B. Estimation of risk factors for COVID-19 mortality - preliminary results. 2020; medRxiv 20027268 [Preprint].2020 Disponible en: https://www.medrxiv.org/content/10.1101/2020.02.24.20027268v1. [Consultado el 3 de junio del 2020].

50. Ong D, de Man S, Lindeboom F, Koeleman J. Comparison of diagnostic accuracies of rapid serological tests and ELISA to molecular diagnostics in patients with suspected COVID-19 presenting to the hospital. Clin Microbiol Infect. 2020; doi: 10.1016/j.cmi.2020.05.028.

51. Cassaniti I, Novazzi F, Giardina F, Salinaro F, Sachs M, Perlini S, et al. Performance of VivaDiag COVID-19 IgM/IgG Rapid Test is inadequate for diagnosis of COVID-19 in acute patients referring to emergency room departmen. J Med Virol. 2020; doi:10.1002/jmv.25800.

52. Zhou Q, Gao Y, Wang X, Liu R, Du P, Wang X, et al. Nosocomial infections among patients with COVID-19, SARS and MERS: A rapid review and meta-analysis. 2020; medRxiv $20065730 \quad$ [Preprint].2020 Disponible en: https://www.medrxiv.org/content/10.1101/2020.04.14.20065730v1. [Consultado el 3 de junio del 2020].

53. Carsana L, Sonzogni A, Nasr A, Rossi R, Pellegrinelli A, Zerbi P, et al. Pulmonary post-mortem findings in a large series of COVID-19 cases from Northern Italy. 2020; medRxiv $20065730 \quad$ [Preprint].2020 Disponible en: 
medRxiv preprint doi: https://doi.org/10.1101/2020.06.14.20130898; this version posted June 16, 2020. The copyright holder for this preprint (which was not certified by peer review) is the author/funder, who has granted medRxiv a license to display the preprint in perpetuity. It is made available under a CC-BY-NC-ND 4.0 International license.

https://www.medrxiv.org/content/10.1101/2020.04.19.20054262v1. [Consultado el 6 de junio del 2020].

54. Schaller T, Hirschbühl K, Burkhardt K, Braun G, Trepel M, Märk1 B, et al. Postmortem Examination of Patients With COVID-19. JAMA. 2020; doi: 10.1001/jama.2020.8907.

55. Endeman H, van der Zee P, van Genderen M, van den Akker J, Gommers D. Progressive respiratory failure in COVID-19: a hypothesis. Lancet Infect Dis 2020. doi: 10.1016/S1473-3099(20)30366-2.

56. Paranjpe I, Fuster V, Lala A, Russak A, Glicksberg B, Levin M, et al. Association of treatment dose anticoagulation with in-hospital survival among hospitalized patients with COVID-19. J Am Coll Cardiol. 2020. doi: 10.1016/j.jacc.2020.05.001.

57. Tang N, Bai H, Chen X, Gong J, Li D, Sun Z. Anticoagulant treatment is associated with decreased mortality in severe coronavirus disease 2019 patients with coagulopathy. J Thromb Haemost 2020;18(5):1094-1099. 
medRxiv preprint doi: https://doi.org/10.1101/2020.06.14.20130898; this version posted June 16, 2020. The copyright holder for this preprint (which was not certified by peer review) is the author/funder, who has granted medRxiv a license to display the preprint in perpetuity.

It is made available under a CC-BY-NC-ND 4.0 International license.

Table 1. Features of 21 patients admitted with Covid 19 at a Regional Reference Center in Valdivia, southern Chile during the first pandemic wave 2020.

\begin{tabular}{lc}
\hline Variable & Results \\
\hline Age in years mean (range) & $61(26-85)$ \\
$\quad$ Age $\geq 60$ years old n (\%) & $12(57.1 \%)$ \\
Female n (\%) & $16(76.2 \%)$ \\
Contact with a known Covid-19 case & $13(61.9 \%)$ \\
Healthcare worker & $1(4.8 \%)$ \\
Previous/current tobacco smoking n (\%) & $2(9.5 \%)$ \\
Use of renin-angiotensin-aldosterone system inhibitors & $9(42.9 \%)$ \\
2020 influenza vaccine & $9(42.9 \%)$ \\
Comorbid conditions/pregnancy n(\%) & \\
Hypertension & $13(61.9 \%)$ \\
Obesity & $12(57.1 \%)$ \\
Diabetes Mellitus type 2 & $8(38.1 \%)$ \\
Asthma /COPD/Lung Fibrosis & $3(14.3 \%)$ \\
Chronic kidney disease & $3(14.3 \%)$ \\
Heart disease & $2(9.5 \%)$ \\
Chronic liver disease & $1(4.8 \%)$ \\
Immunesuppression & $1(4.8 \%)$ \\
Age < 60 without comorbid conditions & $4(19 \%)$ \\
Pregnancy & $2(9.5 \%)^{*}$ \\
\hline
\end{tabular}

*:Both with a second trimester pregnancy 
Table 2. Physical and laboratory parameters at admission among 21 patients admitted with Covid 19 at a Regional Reference Center in Valdivia, southern Chile during the first pandemic wave.

\begin{tabular}{|c|c|}
\hline Parameter & Results \\
\hline Temperature ${ }^{\circ} \mathrm{C}$ median (IQR) & $37.1(36.6-37.8)$ \\
\hline No fever & $4(19 \%)$ \\
\hline Respiratory rate /min median (IQR) & $20(25-34)$ \\
\hline Tachypnea ( $\geq 30 / \min ) \mathrm{n}(\%)$ & $10(47.6 \%)$ \\
\hline Heart rate /min mean (IQR) & $102(81-115)$ \\
\hline $\mathrm{O}_{2}$ pulse digital oxymetry $\%$ median (IQR) & $94 \%(91-96)$ \\
\hline $\mathrm{O}_{2}$ Saturation $<90 \% \mathrm{n}(\%)$ & $4(19 \%)$ \\
\hline $\mathrm{PaO}_{2}$ at admission mmHg median (IQR) & $76.4(69.9-90-4)$ \\
\hline $\mathrm{PaO}_{2}<60 \mathrm{mmHg}$ & $1(4.8 \%)$ \\
\hline PaFiO2 median (IQR) & $295(205-375)$ \\
\hline $\mathrm{PaFiO} 2<300 \mathrm{n}(\%)$ & $12(57.1 \%)$ \\
\hline Blood leucocyte count $/ \mu \mathrm{L}$ median (IQR) & $6730(6310-8690)$ \\
\hline Leucocytosis $>15000 / \mu \mathrm{L}$ & $0(0 \%)$ \\
\hline Blood polymorphonuclear count/ $\mu \mathrm{L}$ median (IQR) & $5400(4700-6800)$ \\
\hline Neutrophilia $>12000 / \mu \mathrm{L}$ & $0(0 \%)$ \\
\hline Lymphocyte count $/ \mu \mathrm{L}$ median (IQR) & $1200(900-1400)$ \\
\hline Lymphocyte count $\leq 1000 / \mu \mathrm{L} \mathrm{n}(\%)$ & $9(42.9 \%)$ \\
\hline Platelet count / $\mu \mathrm{L}$ median (IQR) & $209000(183000-306000)$ \\
\hline Thrombocytopenia $<100000 / \mu \mathrm{L}$ median $\mathrm{n}(\%)$ & $5(23.8 \%)$ \\
\hline $\mathrm{LDH}$ in plasma $\mathrm{U} / \mathrm{L}$ median $(\mathrm{IQR}) *$ & $305(238-467)$ \\
\hline$\leq 250 \mathrm{U} / \mathrm{L}($ normal range $)$ & $6(28.6 \%)$ \\
\hline $250-500 \mathrm{U} / \mathrm{L}$ & $12(57.1 \%)$ \\
\hline$>500 / \mathrm{UL}$ & $1(4.8 \%)$ \\
\hline Blood urea nitrogen mg/dL median (IQR) & $16(10-21)$ \\
\hline $\mathrm{C}$ reactive protein $\mathrm{mg} / \mathrm{L}$ median $(\mathrm{IQR})$ & $9.6(7-14.4)$ \\
\hline International normalized Ratio median (IQR) & $1.12(1.06-1.16)$ \\
\hline Activated partial thromboplastin time median (IQR) sec & $30.4(29-40.8)$ \\
\hline $\mathrm{D}$ dimer $\mu \mathrm{g} / \mathrm{mL}$ median (IQR) & $0.63(0.33-1.58)$ \\
\hline D dimer over normal value $(>0.5 \mu \mathrm{g} / \mathrm{mL})$ & $10(47.6 \%)$ \\
\hline Plasmatic ferritin ng/mL & $552.7(370.4-1168)$ \\
\hline Over normal value (> $150 \mathrm{ng} / \mathrm{mL})$ & $18(85.7 \%)$ \\
\hline$>800 \mathrm{ng} / \mathrm{mL}$ & $6(28.6 \%)$ \\
\hline
\end{tabular}

*: of patients with available results 
Table 3. CALL score, management, complications and outcomes among 21 patients admitted with Covid 19 at a Regional Reference Center in Valdivia, southern Chile during the first pandemic wave.

\begin{tabular}{|c|c|}
\hline Variable & Results \\
\hline \multicolumn{2}{|l|}{ CALL score $\mathrm{n}(\%)$} \\
\hline 4-6 points & $3(14.3 \%)$ \\
\hline 7-9 points & $7(33.3 \%)$ \\
\hline $10-13$ points & $11(52.4 \%)$ \\
\hline \multicolumn{2}{|l|}{ Place of hospitalization $\mathrm{n}(\%)$} \\
\hline General ward & $12(57.1 \%)$ \\
\hline Critical Care Unit & $9(42.9 \%)$ \\
\hline \multicolumn{2}{|l|}{ Ventilatory support $\mathrm{n}(\%)$} \\
\hline Invasive mechanical ventilation & $9(42.9 \%)$ \\
\hline Prone position & $6(28.6 \%)$ \\
\hline Non-invasive mechanical ventilation only & $0(0 \%)$ \\
\hline High-flow nasal cannula & $7(33.3 \%)$ \\
\hline Vaso-active drugs & $8(38.1 \%)$ \\
\hline \multicolumn{2}{|l|}{ Drug Treatment n (\%) } \\
\hline Hydroxychloroquine & $21(100 \%)$ \\
\hline Macrolydes & $10(47.6 \%)$ \\
\hline $\begin{array}{l}\text { High-intermediate doses of low-molecular weight } \\
\text { heparin }\end{array}$ & $6(33.3 \%)$ \\
\hline Corticosteroids & $5(23.8 \%)$ \\
\hline Convalescent plasma & $1(4.8 \%)$ \\
\hline Cesarean section & $1(4.8 \%)$ \\
\hline \multicolumn{2}{|l|}{ Complications n $(\%)$} \\
\hline ARDS & $9(42.9 \%)$ \\
\hline Long QTc interval* & $1(4.8 \%)$ \\
\hline Acute Kidney Injury** & $6(28.6 \%)$ \\
\hline Hospital-acquired infections & $7(33.3 \%)$ \\
\hline \multicolumn{2}{|l|}{ Hospital length of stay } \\
\hline Median (IQR) in days & $18(10-28)$ \\
\hline$\geq 14$ days $n(\%)$ & $12(57.1 \%)$ \\
\hline Deceased n $(\%)$ & $2(9.5 \%)$ \\
\hline
\end{tabular}

*: No arrhythmia associated; **one case with dialysis requirement. 
Table 4. Distribution of results after the first serological evaluation of IgM and IgG anti-SARS-CoV2 antibodies.

\begin{tabular}{|c|c|c|c|c|c|c|}
\hline \multirow{2}{*}{$\begin{array}{l}\text { Weeks elapsed between } \\
\text { symptom onset and } \\
\text { serological sampling }\end{array}$} & \multicolumn{4}{|c|}{ Serological result at first evaluation } & \multirow[b]{2}{*}{ Total } & \multirow[b]{2}{*}{$\begin{array}{l}\text { Cumulative } \% \text { of } \\
\text { positive results per } \\
\text { week }\end{array}$} \\
\hline & Negative both & IgM+ only & $\begin{array}{c}\text { IgM IgG } \\
\text { both positives }\end{array}$ & Invalid result & & \\
\hline 1 & 0 & 2 & 2 & 0 & 4 & $19.0 \%$ \\
\hline 2 & 1 & 0 & 5 & 1 & 7 & $42.9 \%$ \\
\hline 3 & 0 & 0 & 4 & 0 & 4 & $61.9 \%$ \\
\hline 4 & 0 & 0 & 6 & 0 & 6 & $90.5 \%$ \\
\hline Total (Raw \%) & $1(4.8 \%)$ & $2(9.5 \%)$ & $17(81 \%)$ & $1(4.8 \%)$ & $21(100 \%)$ & \\
\hline
\end{tabular}




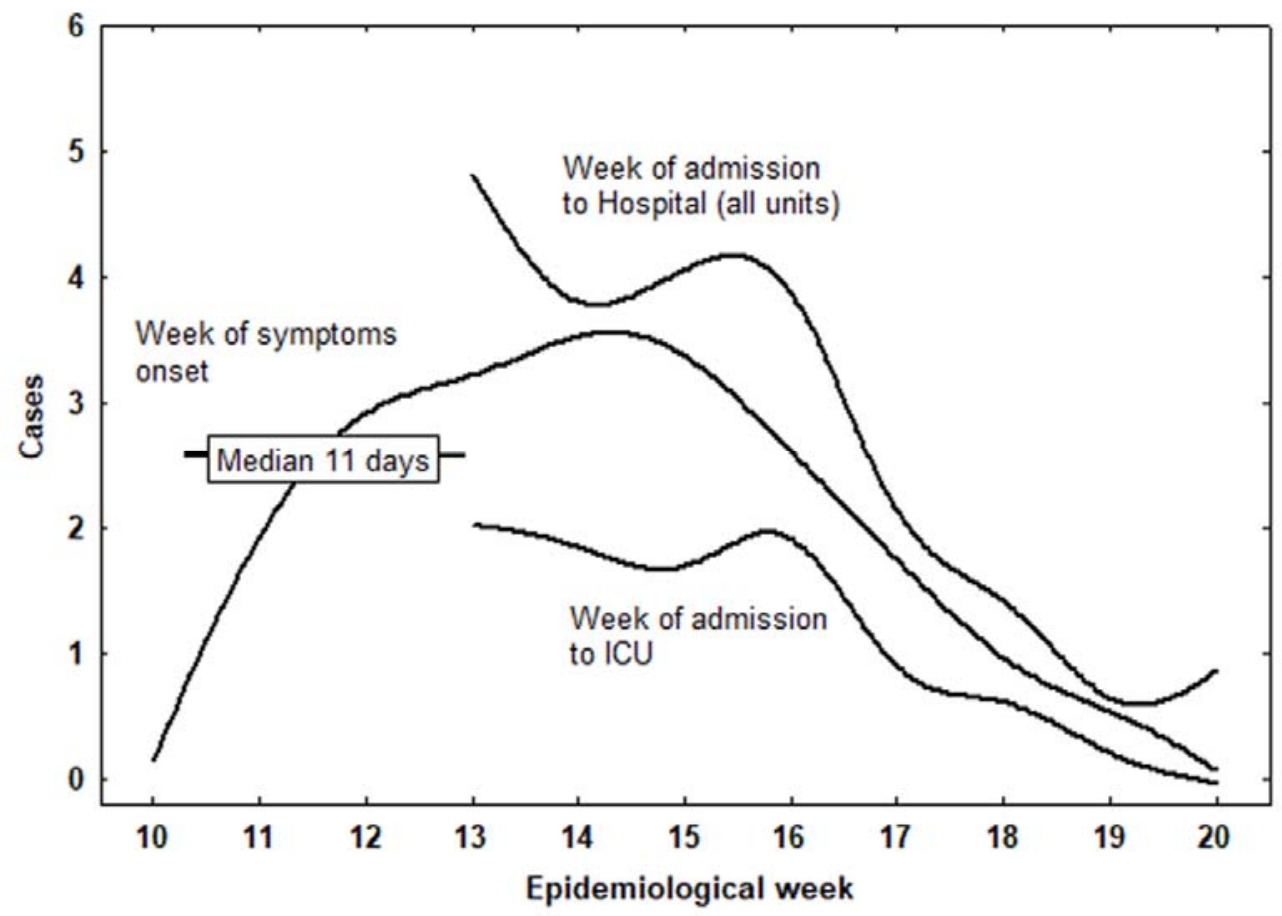

Figure 1. Distribution of cases with Covid-19 admitted to the hospital according to the epidemiological week from symptoms onset to the actual week of hospitalization. More than a week of delay between symptoms onset and admission is observed. Curves were fitted by the least square method 
medRxiv preprint doi: https://doi.org/10.1101/2020.06.14.20130898; this version posted June 16, 2020. The copyright holder for this preprint (which was not certified by peer review) is the author/funder, who has granted medRxiv a license to display the preprint in perpetuity.

It is made available under a CC-BY-NC-ND 4.0 International license .

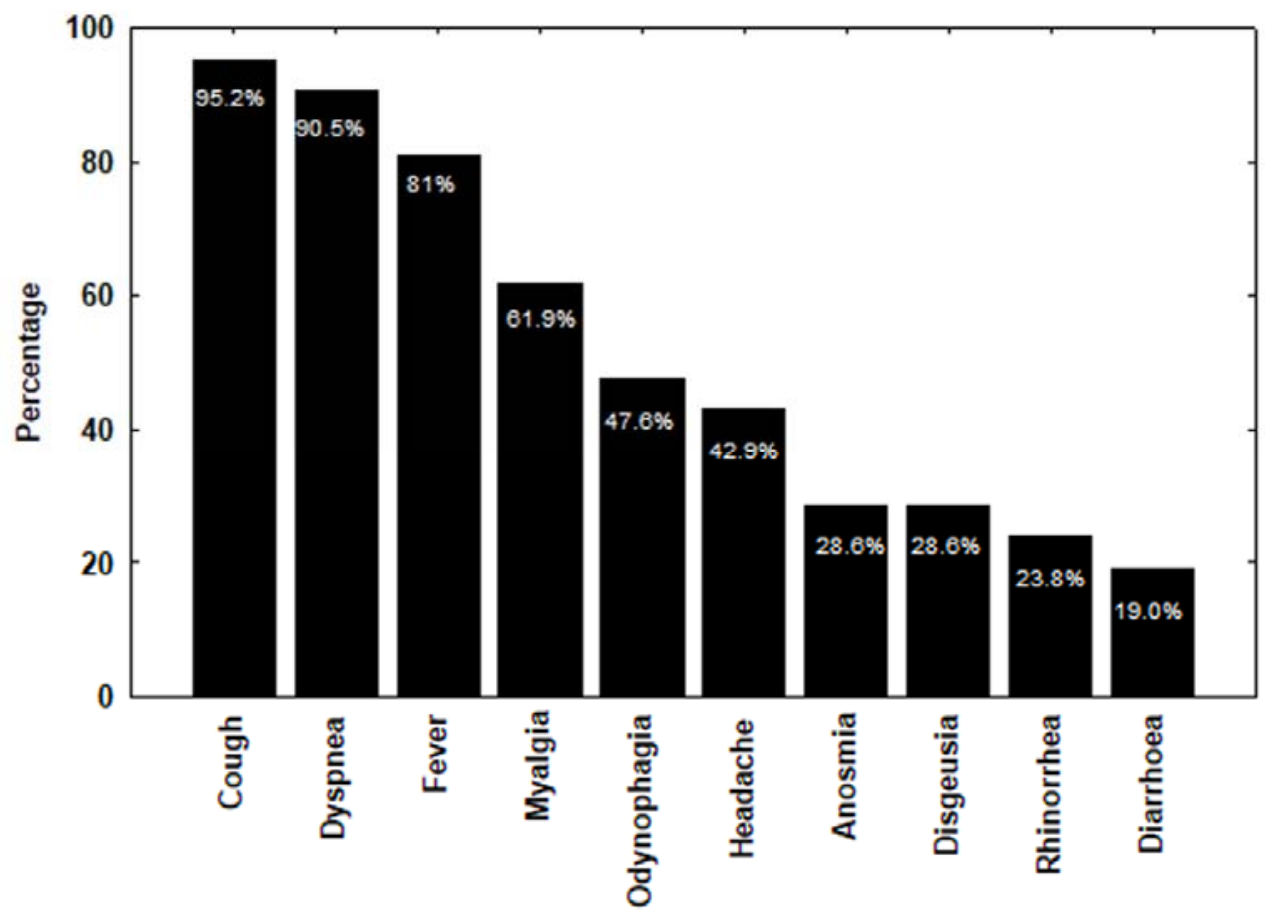

Figure 2. Distribution of symptoms among 21 patients admitted to a Regional Reference Center with Covid 19 in Valdivia, Southern Chile. 
medRxiv preprint doi: https://doi.org/10.1101/2020.06.14.20130898; this version posted June 16, 2020. The copyright holder for this preprint (which was not certified by peer review) is the author/funder, who has granted medRxiv a license to display the preprint in perpetuity.

It is made available under a CC-BY-NC-ND 4.0 International license .

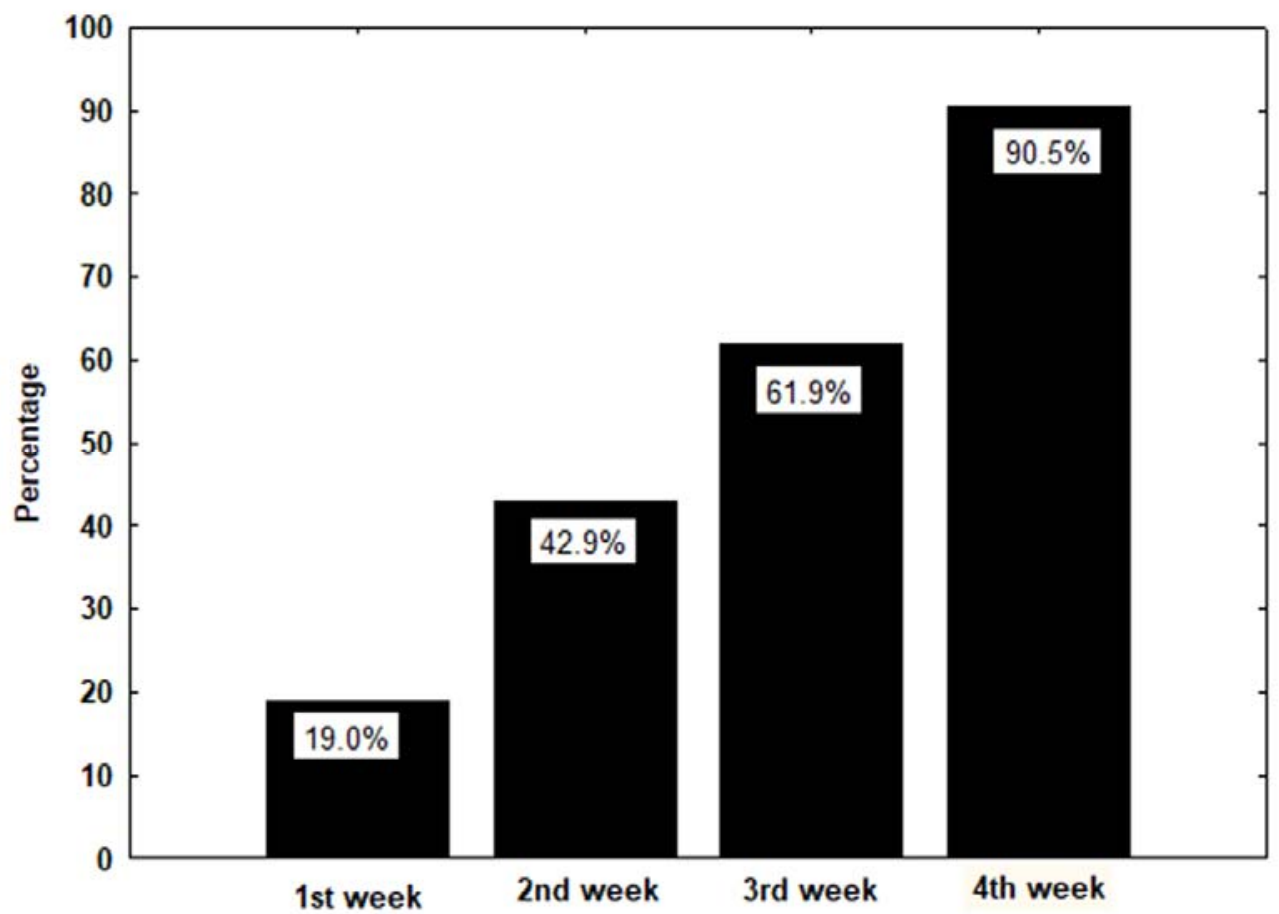

Figure 3. Accumulated sensitivity per week of symptoms onset after the first serological evaluation of IgM and IgG anti-SARS-CoV2 antibodies using a Rapid commercial test. Either a positive $\operatorname{IgM}$ or a combined $\operatorname{IgM} / \operatorname{IgG}$ positive result was considered for analysis. 